\title{
PCBs in fish and their cestode parasites in Lake Victoria
}

\section{John Oluoch-Otiego, Elijah Oyoo-}

\section{Okoth, Kipkorir Koross Godfrey Kiptoo,}

Emily J. Chemoiwa, Charles C. Ngugi,

\section{Gelas Simiyu, et al.}

\section{Environmental Monitoring and} Assessment

An International Journal Devoted to Progress in the Use of Monitoring Data in Assessing Environmental Risks to Man and the Environment

ISSN 0167-6369

Volume 188

Number 8

Environ Monit Assess (2016) 188:1-11

DOI 10.1007/s10661-016-5483-0

\section{ENVIRONMENTAL MONITORING AND ASSESSMENT}

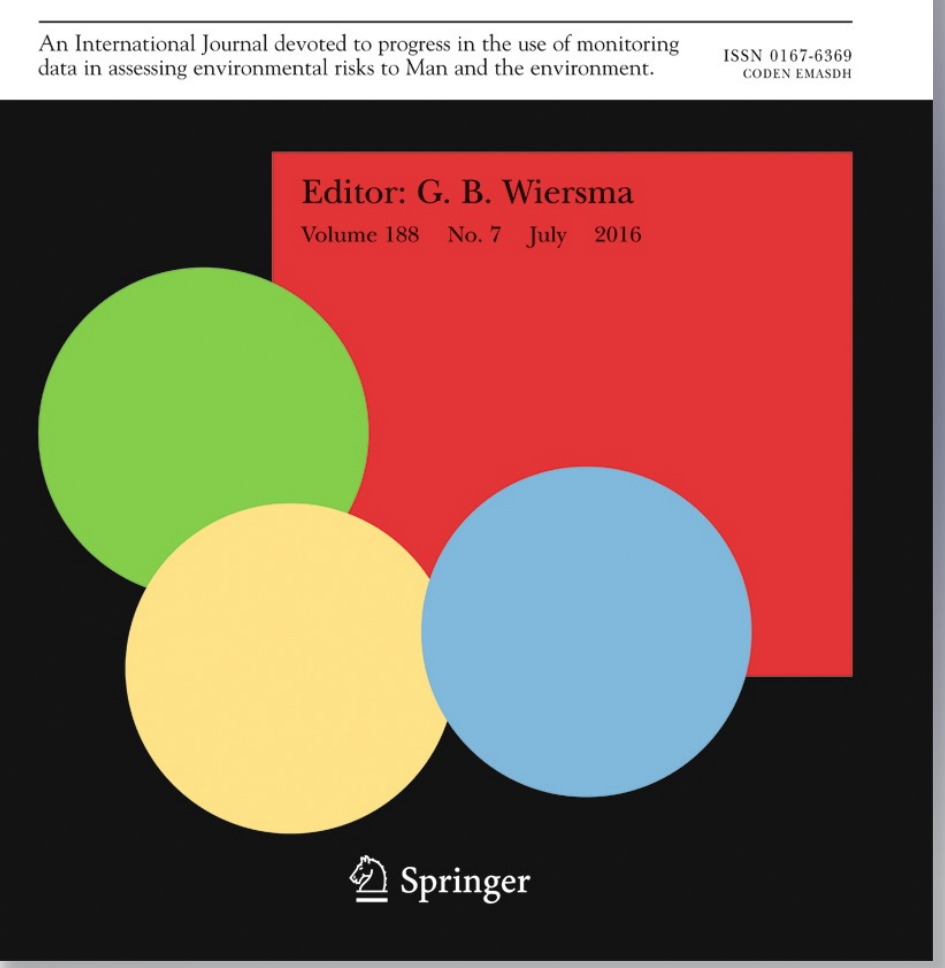

\section{望 Springer}


Your article is protected by copyright and all rights are held exclusively by Springer International Publishing Switzerland. This eoffprint is for personal use only and shall not be self-archived in electronic repositories. If you wish to self-archive your article, please use the accepted manuscript version for posting on your own website. You may further deposit the accepted manuscript version in any repository, provided it is only made publicly available 12 months after official publication or later and provided acknowledgement is given to the original source of publication and a link is inserted to the published article on Springer's website. The link must be accompanied by the following text: "The final publication is available at link.springer.com". 


\title{
PCBs in fish and their cestode parasites in Lake Victoria
}

\author{
John Oluoch-Otiego • Elijah Oyoo-Okoth • Kipkorir Koross Godfrey Kiptoo • \\ Emily J. Chemoiwa • Charles C. Ngugi • Gelas Simiyu • Elijah S. Omutange • \\ Veronica Ngure • Mary A. Opiyo
}

Received: 10 January 2016/Accepted: 13 July 2016

(C) Springer International Publishing Switzerland 2016

\begin{abstract}
Polychlorinated biphenyls (PCBs) are classified as persistent organic pollutants (POPs) regulated by the Stockholm Convention (2001). Although their production and use was stopped almost three decades ago, PCBs are environmental persistent, toxic, and bioaccumulate in biota. We assessed the levels of 7 PCB congeners (IUPAC
\end{abstract}

J. Oluoch-Otiego • K. K. G. Kiptoo • G. Simiyu

Division of Environmental Health, School of Environmental

Studies, University of Eldoret, P.O. Box 1125, Eldoret, Kenya

E. Oyoo-Okoth $(\bowtie)$

School of Natural Resources and Environmental Studies,

Department of Natural Resource, Karatina University,

P.O. Box 1957-10101, Karatina, Kenya

e-mail: elijaoyoo2009@gmail.com

\section{E. J. Chemoiwa}

Department of Biological Sciences, University of Eldoret,

P.O. Box 1125, Eldoret, Kenya

\section{C. Ngugi}

Department of Agricultural Resource Management, Kenyatta University, School of Agriculture and Enterprise Development, P.O. Box 43844-00100, Nairobi, Kenya

E. S. Omutange

Department of Technology Education, Moi University, Eldoret, Kenya, P.O. Box 1125, Eldoret, Kenya

\section{Ngure}

Department of Biological Sciences, Laikipia University,

Nyahururu P.O. Box 1100-20300, Kenya

M. A. Opiyo

Kenya Marine and Fisheries Research Institute, National Aquaculture Research Development and Training Center, P.O. Box 451-10230, Sagana, Kenya nos. $28,52,101,118,138,153$, and 180) in sediment and fish (Oreochromis niloticus, Lates niloticus, and Rastrineobola argentea) and evaluated the potential of cestode fish endoparasite (Monobothrioides sp., Proteocephalaus sp., and Ligula intestinalis) as biomonitors of PCBs in Lake Victoria, Kenya. The median concentration of $\Sigma 7 \mathrm{PCBs}$ in sediments and fish were 2.2$96.3 \mu \mathrm{g} / \mathrm{kg} \mathrm{dw}$ and $300-3,000 \mu \mathrm{g} / \mathrm{kg} \mathrm{lw}$, respectively. At all the sampling sites, CB138, CB153, and CB180 were the dominant $\mathrm{PCB}$ congeners in sediment and fish samples. Compared to the muscle of the piscine host, Proteocephalaus sp. (infecting L. niloticus) biomagnified PCBs $\times 6-14$ while Monobothrioides sp. (infecting O. niloticus) biomagnified PCBs $\times 4-8$. Meanwhile, $L$. intestinalis (infecting $R$. argentea) biomagnified PCBs $\times 8-16$ compared to the muscle of unparasitized fish. We demonstrate the occurrence of moderate to high levels of PCB in sediments and fish in Lake Victoria. We also provide evidence that fish parasites bioaccumulate higher levels of PCBs than their piscine hosts and therefore provide a promising biomonitor of PCBs. We urge further a long-term study to validate the use of the above cestode fish parasites as biomonitoring tools for PCBs.

Keywords PCBs $\cdot$ Bioaccumulation $\cdot$ Parasite $\cdot$ Lipid content $\cdot$ Biomagnification $\cdot$ Lake Victoria

\section{Introduction}

Polychlorinated biphenyls (PCBs) as commercial formulations were employed in the past as dielectric fluids 
in power transformers and capacitors, as insulators, coolants, plasticizers in plastic and rubber products, and as hydraulic fluid (Meijer et al. 2003; Johnson et al. 2006). They may be introduced into the environment through accidental leaks and fires in electrical equipment, past disposal in dumps, accidents in transportation of equipment with PCBs, and leakage from hazardous waste sites (Yang et al. 2009). Since they are regarded as persistent organic pollutants (PoP) by Stockholm Convention, they could seriously threaten the environment, animal, and human health (Brown et al. 1994; Berg et al. 2013; Pizarro-Aránguiz et al. 2015; UNEP 2009), depending on their concentrations, the type of PCB congener, and extent of exposure (Zhang et al. 2014). There are concerns about their persistent and toxic nature that led to their eventual ban on production throughout the world in the late 1970s (Breivik et al. 2007). Despite the ban, their presence is still detectable due to their high biostability and hydrophobicity and because they are resistant to both chemical and biological degradation (Ribas-Fito et al. 2001). Also due to the uncontrolled use of the compounds in the industry and agriculture, PCBs are now ubiquitous contaminants in the environmental media worldwide (Meijer et al. 2003; Xing et al. 2005; Yang et al. 2008).

Once in the aquatic ecosystems, small amounts of PCBs may be re-dissolved at the water-sediment interface or incorporated into sediments (Karvonen et al. 2013; Huang et al. 2015; Colombo et al. 2005) and suspended particulate matter (Eisenreich et al. 1989). They can be taken up by sediment-dwelling organisms (McLeod et al. 2008) or build up in aquatic organisms including fish accumulating to higher levels than those in water and sediments (Sures et al. 1999). Bioaccumulation of PCBs in water biota increases over time depending on PCB concentration in the environment and the type of species (Fu and Wu 2006). Fish that are close to the top of the aquatic food web have a relatively long life span and concentrate high amounts of PCBs (Brázová et al. 2012b). Hence, the concentration of PCBs accumulated in fish may be used as a good tool to assess the degree of PCB pollution of the environment (Fang et al. 2009; Hu et al. 2009; Brázová et al. 2012b).

Parasite infection is potential stressor to organisms and may disrupt a number of physiological processes in their host (Frank et al. 2013). The interactions between parasites and their fish hosts have attracted increasing interests from ecological viewpoint (see reviews in (Oyoo-Okoth et al. 2010b; Lima et al. 2012; Karvonen et al. 2013; Seppälä et al. 2009; Bellay et al. 2015), while studies on the interaction between parasites, their hosts, and pollutants have generated information suitable for developing sentinels for contaminant biomonitoring (Marcogliese and Pietrock 2011; Sures 2007; Oyoo-Okoth et al. 2010a, b). Fish parasites have also previously been used in monitoring inorganic pollution (e.g. see (Sures 2001; Huang et al. 2015; Sures et al. 1999), but research on the accumulation of organic compounds, including PCBs (e.g., Brázová et al. 2012a), is scant in parasitic organisms ( Sures 2004, 2008; Marcogliese and Pietrock 2011; Le et al. 2014; Morrill et al. 2014). To this purpose, the aim of this study was to assess the levels of PCBs in sediments and commercial fish species and also evaluate the potential of fish parasites as bioindicator of PCBs in Lake Victoria, Kenya. The host-parasite assemblages from different sites in the lake were analyzed to characterize spatial changes in the ability of the parasites and their hosts to accumulate PCBs.

\section{Materials and methods}

Study area

Lake Victoria is the largest tropical lake in the world, having a surface area of about $68,800 \mathrm{~km}^{2}$ and a maximum depth of about $70 \mathrm{~m}$. The lake is situated at an altitude of $1,134 \mathrm{~m}$ above sea level and is bordered by Tanzania, Kenya, and Uganda (Fig. 1). The mean annual ambient temperatures in areas adjacent the lake range between 20 and $34{ }^{\circ} \mathrm{C}$. Bimodal rainfall pattern is experienced in the area; long and heavy rains $(1,200$ to $1,600 \mathrm{~mm})$ occur from March to May and the short rains (350 to $550 \mathrm{~mm}$ ) from November to December. There are three commercially exploited fish species: Nile tilapia (Oreochromis niloticus), Nile perch (Lates niloticus), and silver sardine (Rastrineobola argentea). Six sites that receive water from the inflowing rivers from the Kenya side of the lake were selected for this study (Fig. 1). Human activities that include fishing, agriculture, livestock grazing, sugarcane farming, and industrial activities in towns at these sites are described elsewhere (Oyoo-Okoth et al. 2012). 


\section{Sampling strategies}

Fieldwork was carried out between 3rd February to 15th November 2014 covering the dry and rainy season at each of the six selected sampling sites (Fig. 1). Most of the sampling work was conducted in the morning between $7 \mathrm{am}$ to $11 \mathrm{am}$. On each sampling date: sediment, fish, and fish parasite samples were collected. Sediments were collected at the surface (up to $20 \mathrm{~cm}$ ) using Ekmans Grab Sampler. The sediments were transferred to marked polythene bags, placed in an icebox $\left(\sim 4{ }^{\circ} \mathrm{C}\right)$ and transported to the laboratory within $30 \mathrm{~min}$ for analyses. In the field, fish were sampled using pelagic gill nets (mesh size $0.5^{\prime \prime}$ ) and rinsed (ultrapure water) and carefully dissected dorso-ventrally using stainless steel instruments for parasitological examinations of endoparasites. Each dissection instrument was used for specific fish. The internal organs were examined for endoparasites under a dissecting and light microscope. The fish muscles were trimmed carefully to expose any embedded parasite cysts. The observed parasites were isolated, counted and each transferred to a labeled vial, then fixed in $70 \%$ alcohol and sent to the Department of Parasitology, University of Eldoret for identification.
Fig. 1 Map of the Nyanza Gulf in Lake Victoria, Kenya showing the location of the sampling sites

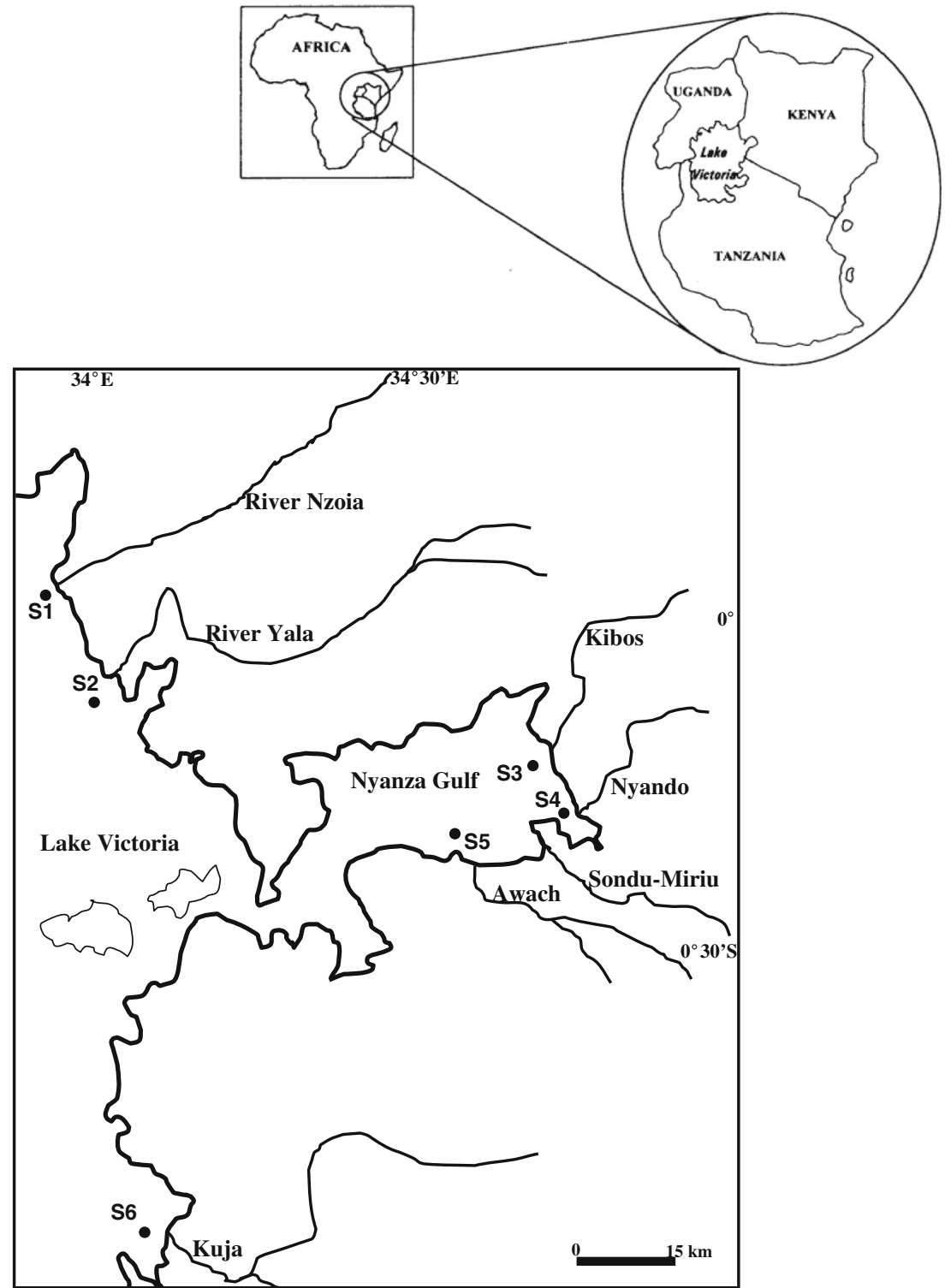


The cestodes were identified morphologically using standard identification keys and pictorial guides, e.g., Yamaguti (1959), Colombo et al. (2005), Sures (2007), and Xing et al. (2005). Data of the fish and parasite samples collected from the six sampling sites of Lake Victoria is presented in Table 1. Other parasites occurred in fish but their prevalence were low $(<2 \%)$ while the cestode parasites that infected one species was not found in the other fish species (i.e., parasite-host specificity). The cestodes for PCB analysis were freeze dried before analysis. Fish which did not have any parasite after field observations were placed into separately marked polythene bags, stored in ice boxes, and transported to the laboratory for further chemical analyses.

Chemical analysis

All samples were freeze dried prior to analysis. In the sediment, the PCBs were measured in the freeze-dried samples; while in fish and fish parasites, the PCBs were measured in the lipid-extracted fractions of the samples. Extraction of lipids followed methods described in (Campbell et al. 2004) with slight modification. Briefly, $2 \mathrm{~g}$ of the freeze-dried sample (sediment, fish, or fish parasites) was ground with $10 \mathrm{~g}$ of anhydrous sodium sulfate using a mortar and pestle. The samples were then extracted on an accelerated solvent extractor device (ASE 300, Dionex, USA) using 1:1 v/v mixture of $n$ hexane/dichloromethane. For the sediments, activated copper granules were added to the extract to remove elemental sulfur before purification with column chromatography. The extract was concentrated to $2 \mathrm{~mL}$ using a rotavapor. The concentrated extract was divided into two sub-samples for fish $(0.3$ and $1.7 \mathrm{~mL})$. The $0.3 \mathrm{~mL}$ was used for gravimetric determination of lipid content while the remaining part was kept for clean up. The extract was cleaned in a silica column to make the extract suitable for injection into the gas chromatograph

Table 1 Data of the fish and parasite samples collected from the six sampling sites of Lake Victoria (mean values \pm standard error)

\begin{tabular}{|c|c|c|c|c|c|c|c|}
\hline \multirow[t]{2}{*}{ Fish/fish parasites } & & \multicolumn{6}{|c|}{ Sampling sites } \\
\hline & & Site S1 & Site S2 & Site S3 & Site S4 & Site S5 & Site 6 \\
\hline \multirow{5}{*}{$\begin{array}{l}\text { Oreochromis } \\
\quad \text { niloticus }\end{array}$} & Number of fish sampled & 189 & 201 & 184 & 192 & 188 & 205 \\
\hline & Mean length (cm) & $40.3 \pm 9.2$ & $43.8 \pm 11.3$ & $37.2 \pm 7.1$ & $38.3 \pm 8.3$ & $41.2 \pm 10.2$ & $43.6 \pm 9.9$ \\
\hline & Mean dry weight (g) & $306.1 \pm 45.3$ & $420.2 \pm 67.8$ & $314.3 \pm 60.2$ & $355.6 \pm 63.2$ & $398.3 \pm 55.2$ & $415.4 \pm 70.2$ \\
\hline & $\begin{array}{l}\text { Prevalence of } \\
\quad \text { Monobothrioides spp. (\%) }\end{array}$ & 23.3 & 22.4 & 20.2 & 24.1 & 21.8 & 20.3 \\
\hline & Number of fish analyzed & 12 & 12 & 12 & 11 & 12 & 12 \\
\hline \multirow[t]{5}{*}{ Lates niloticus } & Number of fish sampled & 133 & 136 & 125 & 144 & 119 & 116 \\
\hline & Mean length (cm) & $50.2 \pm 11.3$ & $55.3 \pm 19.2$ & $48.3 \pm 10.1$ & $49.3 \pm 12.3$ & $52.3 \pm 13.2$ & $56.4 \pm 14.3$ \\
\hline & Mean dry weight (g) & $401.2 \pm 70.3$ & $459.4 \pm 81.2$ & $435.6 \pm 65.6$ & $430.4 \pm 61.4$ & $475.6 \pm 69.3$ & $487.2 \pm 90.2$ \\
\hline & $\begin{array}{l}\text { Prevalence of } \\
\quad \text { Proteocephalus spp. (\%) }\end{array}$ & 37.6 & 40.4 & 40.0 & 37.2 & 37.8 & 42.8 \\
\hline & Number of fish analyzed & 11 & 12 & 12 & 12 & 12 & 12 \\
\hline \multirow{5}{*}{$\begin{array}{l}\text { Rastrineobola } \\
\text { argentea }\end{array}$} & Number of fish sampled & 234 & 142 & 201 & 197 & 210 & 219 \\
\hline & Mean length (mm) & $37.9 \pm 9.4$ & $41.3 \pm 11.2$ & $36.4 \pm 9.1$ & $36.4 \pm 10.2$ & $37.9 \pm 8.9$ & $40.4 \pm 10.1$ \\
\hline & Mean dry weight (g) & $0.54 \pm 0.21$ & $0.58 \pm 0.22$ & $0.51 \pm 0.31$ & $0.49 \pm 0.23$ & $0.54 \pm 0.19$ & $0.56 \pm 0.28$ \\
\hline & $\begin{array}{l}\text { Prevalence of Ligula } \\
\text { intestinallis }(\%)\end{array}$ & 28.6 & 34.5 & 24.9 & 23.4 & 21.4 & 23.7 \\
\hline & Number of fish analyzed & 14 & 12 & 14 & 13 & 12 & 12 \\
\hline \multirow{2}{*}{$\begin{array}{l}\text { Monobothriodes } \\
\text { spp. }\end{array}$} & Number analyzed (n) & 15 & 14 & 15 & 14 & 15 & 15 \\
\hline & Mean abundance in fish & $4.45 \pm 1.16$ & $5.01 \pm 2.42$ & $4.31 \pm 1.49$ & $2.45 \pm 1.19$ & $3.83 \pm 1.56$ & $3.23 \pm 1.99$ \\
\hline \multirow{2}{*}{$\begin{array}{l}\text { Proteocephalus } \\
\text { spp. }\end{array}$} & Number analyzed (n) & 11 & 12 & 12 & 12 & 12 & 12 \\
\hline & Mean abundance in fish & $3.65 \pm 1.19$ & $4.21 \pm 1.82$ & $4.31 \pm 1.09$ & $3.45 \pm 1.31$ & $2.44 \pm 1.41$ & $3.23 \pm 1.92$ \\
\hline \multirow{2}{*}{$\begin{array}{l}\text { Ligula } \\
\quad \text { intestinalis }\end{array}$} & Number analyzed (n) & 15 & 15 & 15 & 14 & 15 & 15 \\
\hline & Mean abundance in fish & $1.45 \pm 0.16$ & $2.41 \pm 0.82$ & $2.31 \pm 0.09$ & $2.45 \pm 1.21$ & $2.43 \pm 0.92$ & $1.23 \pm 1.02$ \\
\hline
\end{tabular}


(GC). The column contained alternating layers of neutral and acidic silica gel. The column was pre-eluted with hexane, the sample was applied, and then the PCBs were eluted with hexane. Finally, the sample was concentrated to a final volume of $100 \mu \mathrm{L}$.

The 7 "indicator" congeners (IUPAC nos. 28, 52, $101,118,138,153$, and 180) have been chosen on the basis of their persistence in food web and their tendency to biomagnification. The analysis of 7 indicator PCBs (IUPAC numbers 28, 52, 101, 118, 138, 153, and 180) was done using high-resolution gas chromatography coupled with high-resolution mass spectrometry (HRGC/HRMS; AutoSpec Ultima, Waters, USA). Chromatographic separation was achieved by injecting $1 \mu \mathrm{L}$ of sample on a fused silica capillary column (DB5MS, $60 \mathrm{~m} \times 0.25 \mathrm{~mm}$ i.d. $\times 0.25 \mu \mathrm{m}$ film thicknesses). The oven temperature of the $\mathrm{GC}$ was maintained at $120^{\circ} \mathrm{C}$ for $1 \mathrm{~min}$, then increased to $150{ }^{\circ} \mathrm{C}$ at a rate of $30{ }^{\circ} \mathrm{C} \mathrm{min}{ }^{-1}$, and finally, to $300{ }^{\circ} \mathrm{C}$ at $2.5^{\circ} \mathrm{C} \mathrm{min}{ }^{-1}$. Helium was used as a carrier gas at a flow rate of $1.0 \mathrm{~mL} / \mathrm{min}$.

\section{Quality assurance and quality control}

To ensure the quality of data, surrogate PCB standards, blanks, replicates, and a certified reference material (NMIJ CRM 7404-a, Japan) were included in the analysis. The PCBs reference standards and other organic solvents and chemicals were of analytical grade and purchased from commercial suppliers. Recoveries for majority of the surrogate standards met the requirements of US EPA methods 1668A (were in the range of 80$117 \%$ ). The recoveries resulting from triplicate determinations $(N=3)$ of the certified reference material were between 81 and $112 \%$ for the PCB congeners. The limit of detection (LOD) which was calculated as three times the signal-to-noise ratio, varied from 0.04 to $0.32 \mathrm{ng} / \mathrm{kg}$ for sediments and 0.02 to $0.60 \mathrm{ng} / \mathrm{kg}$ for fish, and 0.03 to $0.56 \mathrm{ng} / \mathrm{kg}$ parasites.

\section{Biomagnification (BMF) of PCBs in fish parasites}

The biomagnification factor (BMF) of the PCBs in the parasite tissue was calculated according to the formula: Adopted from (Sures et al. 1999). BMF $=$ Concentration of the PCBs in the parasite tissue/Concentration of the $\mathrm{PCBs}$ in the fish muscle.
Data analysis

All statistical analyses were performed with STATISTICA 10.0 (StatSoft, Inc., Tulsa, OK, USA). Data on PCBs concentration are presented as mean \pm SD per site. One-way ANOVA was used to compare concentrations among sites. For each tested data set, the assumption of normality prior to ANOVA was verified using the Shapiro-Wilk test. Significantly different means were analyzed by post hoc Tukey's HSD test. Relationship between PCBs concentration in sediment and fish were analyzed using Pearson's correlation. Significance was declared at $P<0.05$ for all analysis.

\section{Results}

Lipid content of freeze-dried wet weight of the fish were: (mean \pm SEM [range]): O. niloticus $3.2 \pm 0.4$ [2.9-3.7]\%, L. niloticus $5.9 \pm 1.1[5.2-6.4] \%$, and R. argentea $4.9 \pm 0.6[4.8-5.6] \%$ while the lipid content of the parasites were: Monobothrioides sp. $4.4 \pm 0.6$ [4.1-4.7]\%, Protocephalus sp. $5.8 \pm 0.9$ [5.8-6.4]\%, and Ligula intestinalis $6.1 \pm 0.8[5.5-6.7] \%$. The prevalence of Monobothrioides sp. ranged from 20.2 to $24.1 \%$ in $O$. niloticus, Protocephalus sp. ranged from 37.2 to $42.8 \%$, while for $L$. intestinalis the prevalence was $21.4-34.5 \%$.

Concentrations of $\Sigma 7 \mathrm{PCB}$ in sediments, fish, and parasites samples at the six sites is presented in Fig. 2. The mean concentration of $\Sigma 7 \mathrm{PCBs}$ in sediment (a) ranged from 2.2 to $96.4 \mu \mathrm{g} / \mathrm{kg} \mathrm{dw}$ (Fig. 2a). There was a significant spatial variation of PCBs in sediments $(P<0.001)$. S3 had the highest concentration of PCBs (mean $=73.5 \mu \mathrm{g} / \mathrm{kg} \mathrm{dw} ; 31.2-96.4 \mu \mathrm{g} / \mathrm{kg}$ dw range). The PCB levels at S1 (mean $=24.7 \mu \mathrm{g} / \mathrm{kg} \mathrm{dw} ; 17.3-$ $28.7 \mu \mathrm{g} / \mathrm{kg} \mathrm{dw}$ range) followed that of S3. Site S6 (mean $=4.6 \mu \mathrm{g} / \mathrm{kg} \mathrm{dw} ; 2.2-8.1 \mu \mathrm{g} / \mathrm{kg} \mathrm{dw}$ range) had the lowest sedimentary PCB levels.

Concentration of PCBs in fish (b) ranged from 300 to $3,000 \mu \mathrm{g} / \mathrm{kg}$ lw (Fig. 2b). There were notable significant spatial differences in PCB levels $(P<0.001)$; S3 had 2$3 \times$ higher concentration of PCBs (mean $=1450 \mu \mathrm{g} / \mathrm{kg}$ lw; $600-3,000 \mu \mathrm{g} / \mathrm{kg}$ lw range) compared to other sites (300-550 $\mu \mathrm{g} / \mathrm{kg}$ lw range). The pattern of PCB concentration at all the sampling sites followed the pattern: L. niloticus $>R$. argentea $>O$. niloticus. PCB levels in parasites (c) ranged from 1,200 to $18,000 \mu \mathrm{g} / \mathrm{kg} \mathrm{lw}$. 
Fig. 2 Box plots of mean \pm SD of PCBs concentration in: a surface sediments $(\mu \mathrm{g} / \mathrm{kg} \mathrm{dw}), \mathbf{b}$ fish $(\mu \mathrm{g} /$ $\mathrm{kg} \mathrm{lw})$, and $\mathbf{c}$ fish parasites $(\mu \mathrm{g} / \mathrm{kg}$ lw) at six sampling sites of Nyanza Gulf in Lake Victoria. Number of samples per station is presented in Table 1

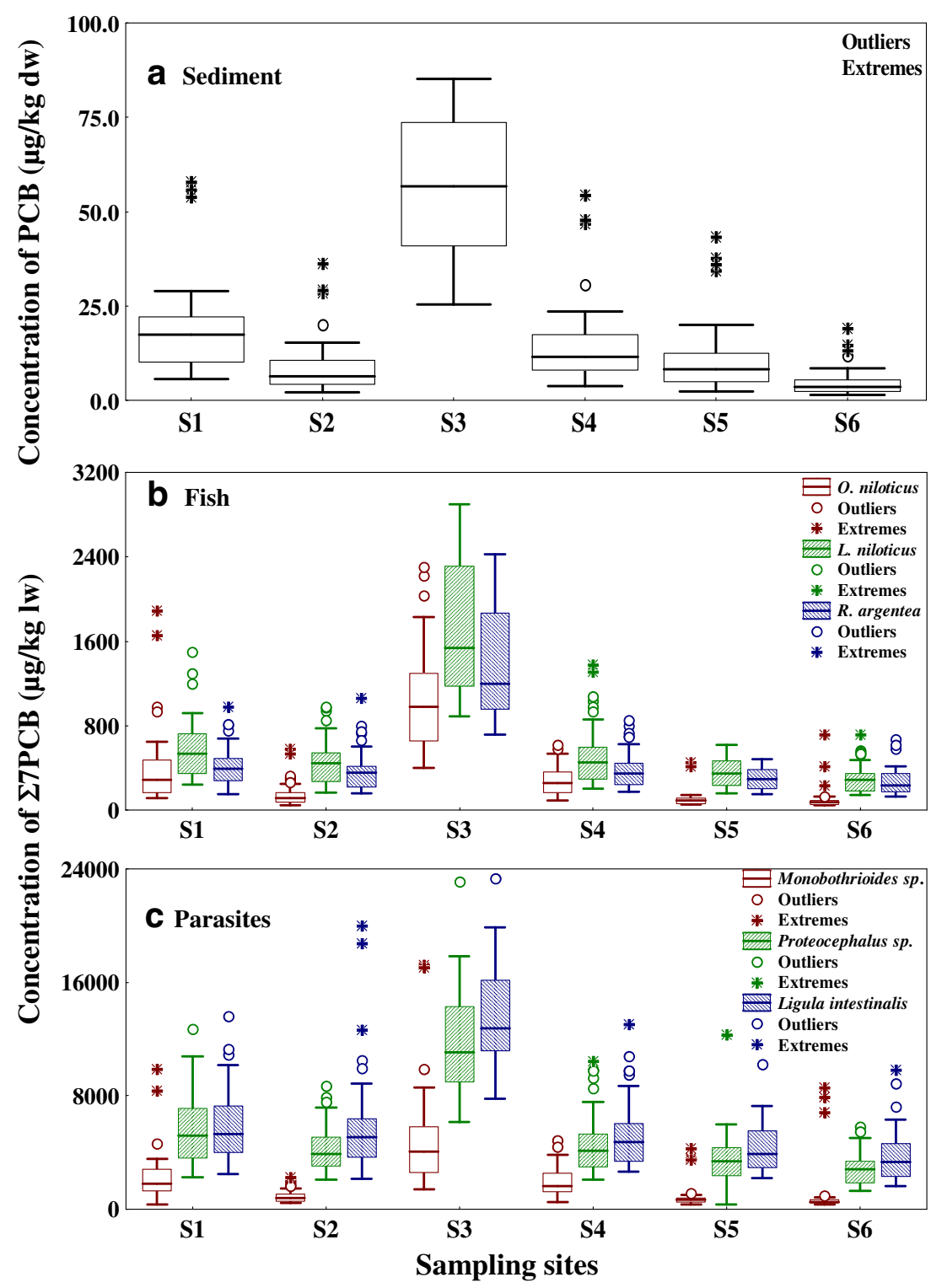

Again there were discernable spatial differences $(P<0.001)$, parasite at $\mathrm{S} 3$ had the highest concentration of PCBs (mean $=13,500-14,500 \mu \mathrm{g} / \mathrm{kg} \mathrm{lw} ; 6,000$ $18,000 \mu \mathrm{g} / \mathrm{kg}$ lw range). The correlation between PCBs in sediments and in fish was significant for all species of fish $(r>0.82, P<0.005)$. Accumulation of PCBs in $L$. intestinalis (parasite infecting $R$. argentea; mean $=12,000 \mu \mathrm{g} / \mathrm{kg} \mathrm{lw} ; 6000-16,000 \mu \mathrm{g} / \mathrm{kg} \mathrm{lw}$ ) was in similar ranges $(P>0.05)$ to accumulation of PCBs in Protocephalus sp. (parasite infecting L. niloticus; mean $=12,000 \mu \mathrm{g} / \mathrm{kg} \mathrm{lw} ; 4,500-13,500 \mu \mathrm{g} / \mathrm{kg} \mathrm{lw}$ ) while Monobothrioides sp. (infecting $O$. niloticus) had the lowest PCB accumulation (mean $=5,400 \mu \mathrm{g} / \mathrm{kg} \mathrm{lw}$; $3,000-7,000 \mu \mathrm{g} / \mathrm{kg} \mathrm{lw}$ ).

We established similar pattern of PCB congeners in sediments, fish, and in parasites. The general concentration patterns (calculated as \% of the $\Sigma 7 \mathrm{PCBs}$ ) is shown in Fig. 3 for the sediment and Fig. 4 for the fish and fish parasites. At all the sampling sites, CB138 (25-32\%), CB153 (27-35\%), and CB180 (17-25\%) were the dominant $\mathrm{PCB}$ congeners in sediment, fish, and parasites. Other congeners (CB28, CB52, CB101, and $\mathrm{CB} 118$ ) occurred at concentrations that were $<10 \%$ each of the congeners at all the sampling sites. 


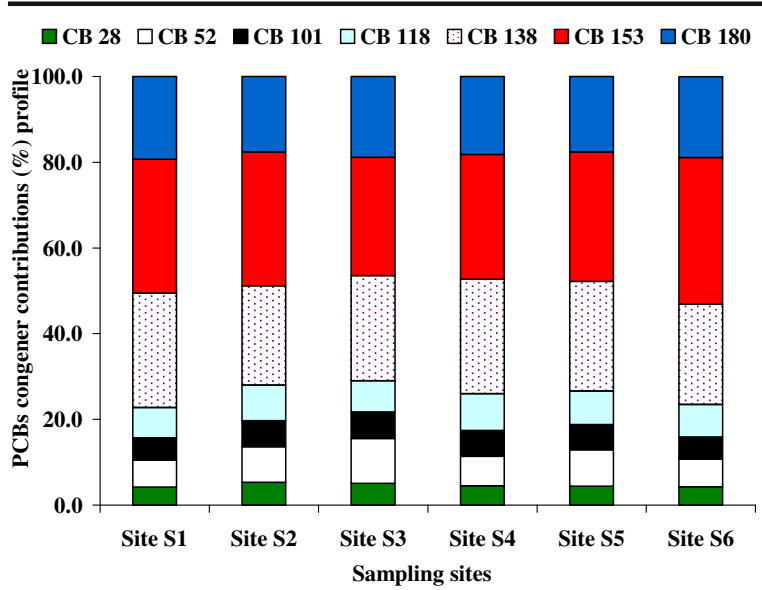

Fig. 3 Pattern of PCB congener contributions (\%) profile in surface sediments at the six sampling sites of the Nyanza Gulf in Lake Victoria, Kenya

The BMF of PCBs in parasite compared to the conspecific fish species is presented in Fig. 5. The fish parasites biomagnified $\mathrm{PCBs} \times 4-16$ without any noticeable spatial differences. Accumulation of PCBs in $L$. intestinalis (parasite infecting $R$. argentea; $\mathrm{BCF} \sim \times 8-16)$ was significantly $(P<0.05)$ higher compared to bioaccumulation in Proteocephalaus sp. (BCF $\sim \times 6-15)$ and Monobothrioides sp. (BCF $\sim \times 4-8)$.

\section{Discussion}

PCBs in sediments

The concentration of $\Sigma 7 \mathrm{PCBs}$ in sediments were higher than those measured in River Pangani, Tanzania (1.3$7.0 \mu \mathrm{g} / \mathrm{kg} \mathrm{dw}$; Hellar-Kihampa et al. 2013), Murchison Bay, Lake Victoria, Uganda $(0.41-4.652 \mu \mathrm{g} / \mathrm{kg} \mathrm{dw}$;

\section{$\Sigma 7 \mathrm{PCB}$ congener contribution $(\%)$ profiles}

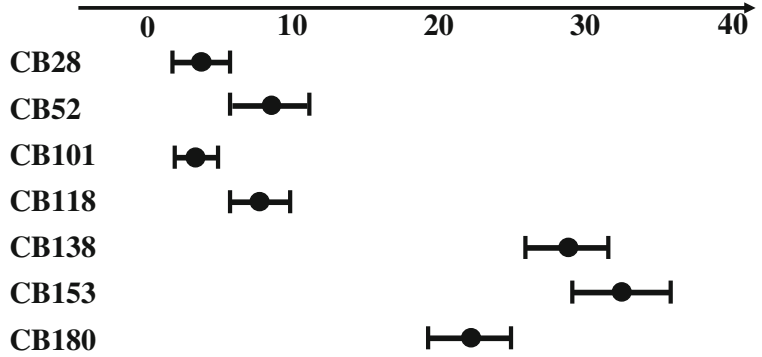

Fig. 4 General pattern of PCB congener contribution (\%) profiles in fish and fish parasites at the six sampling sites of the Nyanza Gulf in Lake Victoria, Kenya. Horizontal bars represent ranges (in $\%$ ) of congeners relative to $\Sigma 7 \mathrm{PCBs}$
Ssebugere et al. 2014b), and Pearl River Delta, South China (0.43-1.77 $\mu \mathrm{g} / \mathrm{kg} \mathrm{dw}$; Wang et al. 2011). These values were also consistently very high compared to River Congo, DRC $(<0.005-0.65 \mu \mathrm{g} / \mathrm{kg} \mathrm{dw}$; Verhaert et al. 2013), in the Napoleon Gulf of Lake Victoria, Uganda (0.04-1.02 $\mu \mathrm{g} / \mathrm{kg}$ dw; Ssebugere et al. 2014a), and those from Guanabara Bay $(0.018-0.184 \mu \mathrm{g} / \mathrm{kg} \mathrm{dw}$; de Souza et al. 2008). PCBs in contaminated site such as S3 were comparable to values reported in Dagu Drainage River in China (9.687-22.148 $\mu \mathrm{g} / \mathrm{kg} \mathrm{dw}$; Liu et al. 2007) and Lake Qarun in Egypt (1.48-137.200 $\mu \mathrm{g} / \mathrm{kg}$ dw; Barakat et al. 2013) but were lower than the upper limits of PCBs in Cortiou, Marseille in France (11.2$1,412.2 \mu \mathrm{g} / \mathrm{kg} \mathrm{dw}$; Wafo et al. 2006).

The rivers that discharge into the L. victoria are located near urban centers with numerous small-scale motor vehicle repair workshops releasing contaminants such as oils and paints which may release contaminants into the rivers draining Lake Victoria. Currently, there is very little enforcement of the regulations on disposal of the wastes into the nearby water bodies (personal observation). Possible PCB contamination sources at the sampling sites also include leakages of contaminated fluids from the electric transformers, motor vehicle lubricants, and heat transfer fluids associated with transportation activities (Ssebugere et al. 2014a). Sites S1, S3, S4, and S5 are also located in catchment areas that practice biomass burning of sugarcane and agroindustrial discharge from sugar industries which is done almost every harvesting season and may be potential source of PCBs (Eckhardt et al. 2007). Site S3 had the highest concentration of PCBs since it is located downstream of urbanized Kisumu City with several chemical manufacturing factories, agro-industries, industrial waste treatment plants, and municipal solid waste incinerators. Its close vicinity to industrial facilities where ships dock are other potential sources of PCBs. The current results indicate higher concentration of PCBs in sediments influenced by human activities in the catchment areas.

\section{PCBs accumulation in fish}

In commercial fish species, the PCB ranges (300$3,000 \mu \mathrm{g} / \mathrm{kg} \mathrm{lw}$ ) were higher than the $\Sigma 7$ PCBs concentration in fish from freshwater bodies in Africa such as Lake Tanganyika (24.3-77.7 $\mu \mathrm{g} / \mathrm{kg}$ lw; Manirakiza et al. 2002), Eastern Slovakia (mean $=108 \mu \mathrm{g} / \mathrm{kg} \mathrm{lw}$; Brázová et al. 2012a), and Van Region, Turkey 
Fig. 5 Box plots of mean \pm SD of biomagnification factor (BMF) of PCBs in fish parasites relative to fish at the six sampling sites of the Nyanza Gulf in Lake Victoria, Kenya

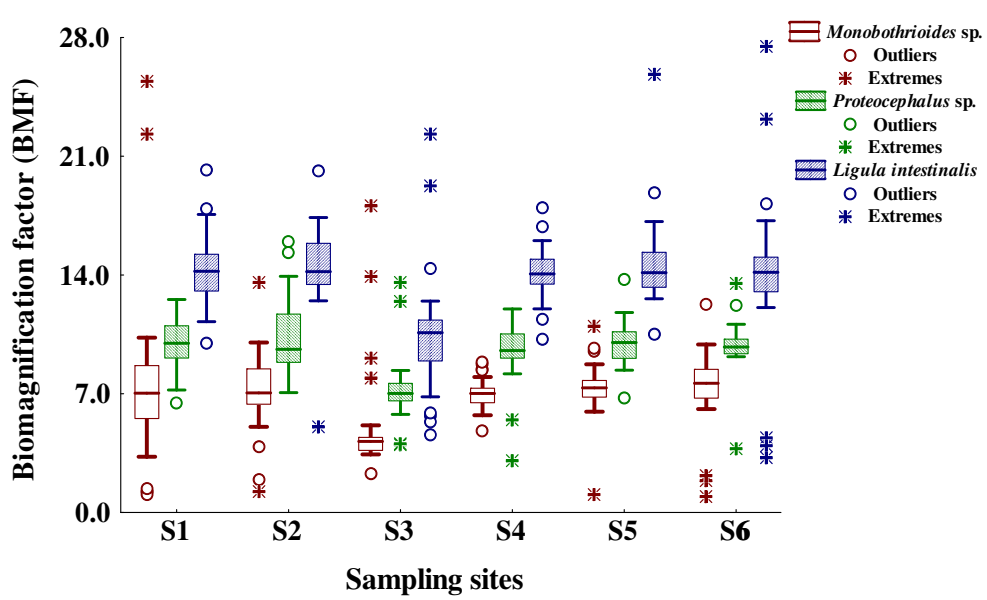

$(<\mathrm{LOD}-277 \mu \mathrm{g} / \mathrm{kg}$ lw; Aksoy et al. 2011). The piscine levels of PCBs were systematically much higher than fish species sampled from upper River Thames $(<0.77-$ $3.32 \mu \mathrm{g} / \mathrm{kg} \mathrm{lw}$; Yamaguchi et al. 2003), Yongxin Island, South China Sea (6.3-89 $\mu \mathrm{g} / \mathrm{kg}$ lw; Sun et al. 2014), and Napoleon Gulf, Lake Victoria, Uganda (0.042$0.778 \mu \mathrm{g} / \mathrm{kg} \mathrm{lw}$; Ssebugere et al. 2014a). The PCBs were comparable to fish species from Negro Basin, Argentinean Patagonia (24.3-77.7 $\mu \mathrm{g} / \mathrm{kg}$ lw; Ondarza et al. 2014), European eel (Anguilla anguila) from Loire Estuary $(80-4,500 \mu \mathrm{g} / \mathrm{kg}$ lw; Blanchet-Letrouvé et al. 2014), and wild brown trouts (Salmo trutta) sampled from Marche rivers, Central Italy $(80-3,100 \mu \mathrm{g} / \mathrm{kg} \mathrm{lw})$ (Frank et al. 2013). The spatial patterns of PCBs were consistent with PCBs analyzed in the sediments; thus, it is possible that exposure to $\mathrm{PCB}-$ contaminated environment via direct contact or ingestion of sedimentdwelling organisms may constitute a major exposure route for fish. When analyzing these differences, one must take into account the trophic niche of the three species (Ojwang et al. 2004; Campbell et al. 2004), since they show different feeding habits, and thus, different positions in the trophic web.

In the present study, PCBs were higher in L. niloticus, a carnivorous species when compared to omnivorous $O$. niloticus and $R$. argentea. The present observations suggest that these compounds can biomagnify throughout the food web to higher levels in the top predators. The higher PCB accumulated by L. niloticus than other fish species therefore appear related to the diet in its trophic position. L. niloticus consume all available fish species including its own siblings, insects, crustacea, and molluscs whereas $O$. niloticus and $R$. argentea rely on zooplankton and macroinvertebrates. The high levels of PCB 138, 153, and 180 most likely demonstrate that more of these congeners were released into the environment. Also, the high degree of chlorination resulting in lower chemical degradation rates may make them be retained in aquatic systems to a greater degree, resulting in bioaccumulation in sediments and biota (Lavandier et al. 2013). These results indicate considerable quantities of PCBs in the environment and therefore, there is a need to search for suitable tools to monitor the PCB concentrations.

PCBs accumulation by fish parasites

Previous study in Lake Victoria have identified that the populations of $R$. argentea in Lake Victoria, exhibit a high degree of infestation with the tapeworm, L. intestinalis, a cestode of the family Diphyllobothriidae (Oyoo-Okoth et al. 2010a, c). Information on the cestode parasitic infections of $O$. niloticus and L. niloticus are absent. In the current study, the prevalence of Monobothrioides sp. occurred in high abundance in $O$. niloticus samples (20.2 to $24.1 \%$ ), Protocephalus sp. in L. niloticus (37.2-42.8\%), and L. intestinalis in $R$. argentea samples (21.4-34.5\%; Table 1). Numerous studies have highlighted parasites as excellent bioaccumulators of inorganic pollutants such as metals compared to their fish hosts. This has often been achieved by calculating BMF, reflecting the ratio between the concentrations in the parasite and in the host. Yet the few studies that have attempted to measure organic compounds such as PCBs bioaccumulation in parasites compared their fish hosts. The studies available have established that these contaminants are lower in parasites than that in host tissues when 
measurement are done as dry weight or wet weight basis, e.g., Brázová et al. (2012a) and Le et al. (2014).

In this study, we used lipid-normalized concentrations of PCBs in the host and compared with that of the cestodes to establish the potential role of parasites as bioaccumulators of PCBs. The cestode infecting the three different fish species contained higher concentration of PCBs than their host by a BMF ranging from $\times 4$ to 16 that was consistent among the sampling sites. The present result where PCBs are higher in parasites than in the hosts are consistent with studies of PCB accumulation in perch (Perca fluviatilis) compared to their parasites (Acanthocephalus lucii; Brázová et al. 2012a) but are inconsistent with studies of the accumulation of PCBs in salmon (Salmo salar) infected with the tapeworm Eubothrium crassum (Persson et al. 2007). A characteristic feature of all cestodes is the absence of an alimentary canal (Karvonen et al. 2013). The lack of an alimentary tract means that substances enter the cestodes across the tegument. This structure is well adapted for transport functions, since it is covered with numerous microvilli resembling those lining the lumen of the mammalian intestine (Bellay et al. 2015). It has also been hypothesized that because cestodes cannot synthesize their own cholesterols and fatty acids, they efficiently obtain them from their host's intestinal lumen (Yang et al. 2009). Absorption of PCBs with the content of the host intestinal lumen is thus probable.

In studies of metal accumulation, a biokinetic model that explores the variability in metal accumulation in situ has been applied to explain the variable bioaccumulation in organisms (McLeod et al. 2008). According to the model, uptake and depuration parameters can be estimated experimentally to provide testable predictions. We previously showed that $R$. argentea had lower uptake rate constant for cadmium which was apparently sequestered well, while L. intestinalis had higher uptake rates of metals and low depuration rate resulting to accumulation of higher amounts of $\mathrm{Cd}$ in parasites than the fish host (Johnson et al. 2006). Currently, we lack information on the uptake and depuration kinetics of PCBs in fish and their respective parasites, and thus, we have very little knowledge on the mechanistic explanation of high bioaccumulation of PCBs in different fish species and parasites to warranty any conclusion. The current results indicate higher concentration of PCBs in parasites compared to the muscle of the fish host and offer a possibility of studying further the prospect of developing parasite-fish model for biomonitoring PCBs.

\section{Conclusion}

In conclusion, this study provide data indicating that the PCBs levels in Lake Victoria are moderate to high and in some sites, it is comparable with ranges of the PCB values found in other places of the world. The high $\mathrm{PCB}$ in the sediments due to increase from diverse human activities are taken up by the fish and their parasites. Comparatively, fish endoparasites biomagnified PCBs than levels in the fish hosts. For this, cestode parasites are potential biomonitors of the degree of accumulation of PCBs in the aquatic environment and show corresponding increase with levels of PCBs in sediments and fish.

Acknowledgments This study was funded by grants from the The Netherlands Government through NWO-WOTRO (grant no. W 01.83.2004.023) and partial funds from the Global Livestock Collaborative Research Support Program (GL-CRSP Grant No. LAG-G-00-96-90015-00. The lead also author also obtained additional funds from the Kenyan government through the National Council for Science and Technology (NCST) and Moi University Research Fund (MURF). We are grateful to ILRI who assisted in laboratory sample preparation and analysis.

\section{References}

Aksoy, A., Das, Y. K., Yavuz, O., Guvenc, D., Atmaca, E., \& Agaoglu, S. (2011). Organochlorine pesticide and polychlorinated biphenyls levels in fish and mussel in van region Turkey. Bulletin of Environmental Contamination and Toxicology, 87, 65-69.

Barakat, A. O., Khairy, M., \& Aukaily, I. (2013). Persistent organochlorine pesticide and PCB residues in surface sediments of Lake Qarun, a protected area of Egypt. Chemosphere, 90, 2467-2476.

Bellay, S., de Oliveira, E. F., Almeida-Neto, M., Abdallah, V. D., de Azevedo, R. K., Takemoto, R. M., et al. (2015). The patterns of organisation and structure of interactions in a fish-parasite network of a neotropical river. International Journal for Parasitology, 45, 549-557.

Berg, V., Zerihun, M. A., Jørgensen, A., Lie, E., Dale, O. B., Skaare, J. U., et al. (2013). High prevalence of infections and pathological changes in burbot (Lota lota) from a polluted lake (Lake Mjøsa, Norway). Chemosphere, 90, 17111718.

Blanchet-Letrouvé, I., Zalouk-Vergnoux, A., Vénisseau, A., Couderc, M., Le Bizec, B., Elie, P., et al. (2014). Dioxin-like, non-dioxin like $\mathrm{PCB}$ and $\mathrm{PCDD} / \mathrm{F}$ contamination in European eel (Anguilla anguilla) from the Loire estuarine continuum: spatial and biological variabilities. Science of the Total Environment, 472, 562-571.

Brázová, T., Hanzelová, V., \& Miklisová, D. (2012a). Bioaccumulation of six PCB indicator congeners in a heavily 
polluted water reservoir in eastern Slovakia: tissue-specific distribution in fish and their parasites. Parasitology Research, 111, 779-786.

Brázová, T., Hanzelová, V., Miklisová, D., Šalgovičová, D., \& Turčeková, L'. (2012b). Biomonitoring of polychlorinated biphenyls (PCBs) in heavily polluted aquatic environment in different fish species. Environmental Monitoring and Assessment, 184, 6553-6561.

Breivik, K., Sweetman, A., Pacyna, J. M., \& Jones, K. C. (2007). Towards a global historical emission inventory for selected PCB congeners - a mass balance approach-3. An update. Science of the Total Environment, 377, 296-307.

Brown, J. F., Lawton, R. W., \& Morgan, C. B. (1994). PCB metabolism, persistence, and health effects after occupational exposure: implications for risk assessment. Chemosphere, 29, 2287-2294.

Campbell, L. M., Hecky, R. E., \& Wandera, S. B. (2004). Stable isotope analyses of food web structure and fish diet in Napoleon and Winam gulfs, Lake Victoria, East Africa. Journal of Great Lakes Research, 29, 243-257.

Colombo, J., Cappelletti, N., Barreda, A., Migoya, M. C., \& Skorupka, C. N. (2005). Vertical fluxes and accumulation of PCBs in coastal sediments of the Río de la Plata estuary, Argentina. Chemosphere, 61, 1345-1357.

de Souza, A. S., Torres, J. P., Meire, R. O., Neves, R. C., Couri, M. S., \& Serejo, C. S. (2008). Organochlorine pesticides (OCs) and polychlorinated biphenyls (PCBs) in sediments and crabs (Chasmagnathus granulata, Dana, 1851) from mangroves of Guanabara Bay, Rio de Janeiro state, Brazil. Chemosphere, 73, 186-192.

Eckhardt, S., Breivik, K., Manø, S., \& Stohl, A. (2007). Record high peaks in PCB concentrations in the Arctic atmosphere due to long-range transport of biomass burning emissions. Atmospheric Chemistry and Physics, 7, 4527-4536.

Eisenreich, S. J., Capel, P. D., Robbins, J. A., \& Bourbonniere, R. (1989). Accumulation and diagenesis of chlorinated hydrocarbons in lacustrine sediments. Environmental Science \& Technology, 23, 1116-1126.

Fang, J. K. H., Wu, R. S. S., Zheng, G. J., Au, D. W. T., Lam, P. K. S., \& Shin, P. K. S. (2009). The use of muscle burden in rabbitfish Siganus oramin for monitoring of polycyclic aromatic hydrocarbons and polychlorinated biphenyls in Victoria harbour, Hong Kong and potential human health risk. Science of the Total Environment, 407, 4327-4332.

Frank, S. N., Godehardt, S., Nachev, M., Trubiroha, A., Kloas, W., \& Sures, B. (2013). Influence of the cestode Ligula intestinalis and the acanthocephalan Polymorphus minutus on levels of heat shock protein 70 (HSP70) and metallothionein in their fish and crustacean intermediate hosts. Environmental Pollution, 180, 173-179.

Fu, C. T., \& Wu, S. C. (2006). Seasonal variation of the distribution of PCBs in sediments and biota in a PCB-contaminated estuary. Chemosphere, 62, 1786-1794.

Hellar-Kihampa, H., De Wael, K., Lugwisha, E., Malarvannan, G., Covaci, A., \& Van Grieken, R. (2013). Spatial monitoring of organohalogen compounds in surface water and sediments of a rural-urban river basin in Tanzania. Science of the Total Environment, 447, 186-197.

Hu, G., Sun, C., Li, J., Zhao, Y., Wang, H., \& Li, Y. (2009). POPs accumulated in fish and benthos bodies taken from Yangtze River in Jiangsu area. Ecotoxicology, 18, 647-651.
Huang, J., Amuzu-Sefordzi, B., \& Li, M. (2015). Heavy metals and polychlorinated biphenyls (PCBs) sedimentation in the Lianhua Mountain reservoir, Pearl River Delta, China. Environmental Monitoring and Assessment, 187, 254.

Johnson, G. W., Chiarenzelli, J., Quensen, J. F., \& Hamilton, M. C. (2006). Polychlorinated biphenyls. Environmental Forensic: A Contaminant Specific Guide, 10, 187-205.

Karvonen, A., Lundsgaard-Hansen, B., Jokela, J., \& Seehausen, O. (2013). Differentiation in parasitism among ecotypes of whitefish segregating along depth gradients. Oikos, 122, $122-128$.

Lavandier, R., Quinete, N., Hauser-Davis, R. A., Dias, P. S., Taniguchi, S., Montone, R., et al. (2013). Polychlorinated biphenyls (PCBs) and polybrominated diphenyl ethers (PBDEs) in three fish species from an estuary in the southeastern coast of Brazil. Chemosphere, 90, 2435-2443.

Le, T. T. Y., Rijsdijka, L., Sures, B., \& Hendriksa, A. J. (2014). Accumulation of persistent organic pollutants in parasites. Chemosphere, 108, 145-151.

Lima, D. P., Giacomini, H. C., Takemoto, R. M., Agostinho, A. A., \& Bini, L. M. (2012). Patterns of interactions of a large fishparasite network in a tropical floodplain. The Journal of Animal Ecology, 81, 905-913.

Liu, H., Zhang, Q., Wang, Y., Cai, Z., \& Jiang, G. (2007). Occurrence of polychlorinated dibenzo-p-dioxins, dibenzofurans and biphenyls pollution in sediments from the Haihe River and Dagu Drainage River in Tianjin City, China. Chemosphere, 68, 1772-1778.

Manirakiza, P., Covaci, A., Nizigiymana, L., Ntakimazi, G., \& P., S. (2002). Persistent chlorinated pesticides and polychlorinated biphenyls in selected fish species from Lake Tanganyika, Burundi, Africa. Environmental Pollution, 117, 447-455.

Marcogliese, D. J., \& Pietrock, M. (2011). Combined effects of parasites and contaminants on animal health: parasites do matter. Trends in Parasitology, 27, 123-130.

McLeod, P. B., Luoma, S. N., \& Luthy, R. G. (2008). Biodynamic modeling of PCB uptake by Macoma balthica and Corbicula fluminea from sediment amended with activated carbon. Environmental Science \& Technology, 42, 484-490.

Meijer, N. S., Ockenden, A. W., Sweetman, A., Brevik, K., Grimalt, O. J., \& Jones, C. K. (2003). Global distribution and budget of PCBs and HCB in background surface soils: implications for sources and environmental processes. Environmental Science \& Technology, 37, 667-672.

Morrill, A., Provencher, J., \& Forbes, M. (2014). Testing for dual impacts of contaminants and parasites on hosts: the importance of skew. Environmental Reviews, 22, 445-456.

Ojwang, W. O., Kaufman, L., Asila, A. A., Agembe, S., \& Michener, B. (2004). Isotopic evidence of functional overlap amongst the resilient pelagic fishes. Hydrobiologia(529), 2734.

Ondarza, P. M., Gonzalez, M., Fillmann, G., \& Miglioranza, K. S. B. (2014). PBDEs, PCBs and organochlorine pesticides distribution in edible fish from Negro River basin, Argentinean Patagonia. Chemosphere, 94, 135-142.

Oyoo-Okoth, E., Admiraal, W., Osano, O., Hoitinga, L., \& Kraak, M. H. S. (2010a). Metal specific partitioning in a parasitehost assemblage of the cestode Ligula intestinalis and the cyprinid fish Rastrineobola argentea. Science of the Total Environment, 408, 1557-1562. 
Oyoo-Okoth, E., Admiraal, W., Osano, O., Kraak, M. H. S., Ngure, V., Makwali, J., et al. (2010b). Use of fish endoparasite Ligula intestinalis in an intermediate cyprinid host (Rastrineobola argentea) in biomonitoring contaminant metals $(\mathrm{Pb}, \mathrm{Cd}, \mathrm{Cr}$ and $\mathrm{Cu})$ in Lake Victoria, Kenya. Lakes \& Reservoirs: Research \& Management, 15, 63-73.

Oyoo-Okoth, E., Admiraal, W., Osano, O., Kraak, M. H. S., Ngure, V., Makwali, J., et al. (2010c). Use of the fish endoparasite Ligula intestinalis (L., 1758) in an intermediate cyprinid host (Rastrineobola argentea) for biomonitoring heavy metal contamination in Lake Victoria, Kenya. Lake. Reserv. Manage, 15, 63-73.

Oyoo-Okoth, E., Admiraal, W., Osano, O., \& Kraak, M. H. S. (2012). Element profiles in hair and nails of children reflect the uptake from food and the environment. Environmental Toxicology and Chemistry, 31, 1461-1469.

Persson, M., Larsson, P., \& Stenroth, P. (2007). Biomagnification and polychlorinated biphenyl congener distribution in an aquatic predator-prey, host-parasite system. Environmental Toxicology and Chemistry, 26, 837-843.

Pizarro-Aránguiz, N., Galbán-Malagón, C. J., Ruiz-Rudolph, P., Araya-Jordan, C., Maddaleno, A., \& San Martin, B. (2015). Occurrence, variability and human exposure to polychlorinated Dibenzo-p-dioxins (PCDDs), polychlorinated Dibenzofurans (PCDFs) and dioxin-like polychlorinated biphenyls (DL-PCBs) in dairy products from Chile during the 2011-2013 survey. Chemosphere, 126, 7887.

Ribas-Fito, N., Sala, M., Kogevinas, M., \& Sunyer, J. (2001). Polychlorinated biphenyls (PCBs) and neurological development in children: a systematic review. Journal of Epidemiology and Community Health, 55, 537-546.

Seppälä, O., Karvonen, A., Valtonen, E. T., \& Jokela, J. (2009). Interactions among co-infecting parasite species: a mechanism maintaining genetic variation in parasites? Proceedings of the Royal Society B, 276, 691-697.

Ssebugere, P., Sillanpää, M., Kiremire, B. T., Kasozi, G. N., Wang, P., Sojinu, S. O., et al. (2014a). Polychlorinated biphenyls and hexachlorocyclohexanes in sediments and fish species from the Napoleon gulf of Lake Victoria, Uganda. Science of the Total Environment, 48, 55-60.

Ssebugere, P., Sillanpää, M., Wang, P., Li, Y., Kiremire, B. T., Kasozi, G. N., et al. (2014b). Polychlorinated biphenyls in sediments and fish species from the Murchison Bay of Lake Victoria, Uganda. Science of the Total Environment, 482483, 349-357.

Sun, Y. X., Hao, Q., Xu, X. R., Luo, X. J., Wang, S. L., Zhang, Z. W., et al. (2014). Persistent organic pollutants in marine fish from Yongxing Island, South China Sea: levels, composition profiles and human dietary exposure assessment. Chemosphere, 98, 84-90.
Sures, B. (2001). The use of fish parasites as bioindicators of heavy metals in aquatic ecosystems, a review. Aquatic Ecology, 35, 245-255.

Sures, B. (2004). Environmental parasitology: relevancy of parasites in monitoring environmental pollution. Trends in Parasitology, 20, 170-177.

Sures, B. (2007). Host-parasite interactions from an ecotoxicological perspective. Parassitologia, 49, 173-176.

Sures, B. (2008). Host-parasite interactions in polluted environments. Journal of Fish Biology, 73, 2133-2142.

Sures, B., Siddall, R., \& Taraschewski, H. (1999). Parasites as accumulation indicators of heavy metal pollution. Parasitology Today, 50, 16-21.

UNEP (2009). Stockholm convention on persistent organic pollutants (POPs). Geneva: Published by the Secretariat of the Stockholm Convention on Persistent Organic Pollutants.

Verhaert, V., Covaci, A., Bouillon, S., Abrantes, K., Musibono, D., Bervoets, L., et al. (2013). Baseline levels and trophic transfer of persistent organic pollutants in sediments and biota from the Congo River basin (DR Congo). Environment International, 59, 290-302.

Wafo, E., Sarrazin, L., Diana, C., Schembri, T., Lagadec, V., \& Monod, J. L. (2006). Polychlorinated biphenyls and DDT residues distribution in sediments of Cortiou (Marseille, France). Marine Pollution Bulletin, 52, 104-107.

Wang, H. S., Du, J., Leung, H. M., Leung, A. O. W., Liang, P., Giesy, J. P., et al. (2011). Distribution and source apportionments of polychlorinated biphenyls (PCBs) in mariculture sediments from the Pearl River Delta, South China. Marine Pollution Bulletin, 63, 516-522.

Xing, Y., Lu, Y., Dawson, R. W., Shi, Y., Zhang, H., Wang, T., et al. (2005). A spatial temporal assessment of pollution from PCBs in China. Chemosphere, 60, 731-739.

Yamaguchi, N., Gazzard, D., Scholey, G., \& Macdonald, D. W. (2003). Concentrations and hazard assessment of PCBs, organochlorine pesticides and mercury in fish species from the upper Thames: river pollution and its potential effects on top predators. Chemosphere, 50, 265-273.

Yamaguti, S. (1959). Systema Helminthum. II. The Cestodes of vertebrates. New York \& London: Interscience Publishers.

Yang, F., Wilcox, B., Jin, S., Aguirre, A. A., Rougée, L., Xu, Y., et al. (2008). Detection and quantitative analysis of polychlorinated biphenyls in tilapia from Hawaiian waters. Chemosphere, 73, 133-137.

Yang, Z., Shen, Z., Gao, F., Tang, Z., \& Niu, J. (2009). Occurrence and possible sources of polychlorinated biphenyls in surface sediments. Chemosphere, 74, 1522-1530.

Zhang, Q., Ye, J., Chen, J., Xu, H., Wang, C., \& Zhao, M. (2014). Risk assessment of polychlorinated biphenyls and heavy metals in soils of an abandoned e-waste site in China. Environmental Pollution, 185, 258-265. 